\title{
DESIGN OF ENGLISH LEARNING BASED ON LIVE STREAMING OF DIGITAL ERA IN COVID-19
}

\author{
Faidah Yusuf \\ English and Literature Department, Faculty of Adab and Humanities \\ Universitas Islam Negeri Makassar, Indonesia. \\ Email: faidah.yusuf@uin-alauddin.ac.id
}

\begin{abstract}
The important of this paper is live streaming using gadget as a learning English speaking in Covid-19 era relying on the internet and utilizing the social media platform facebook. This research is a descriptive qualitative study, used on 40 students. The result identified seven steps to create a Facebook group and learning tool to produce lecture units, student activity sheets, and student worksheets. The analysis of this study discussed the seven steps of English learning design of English learning devices based on live streaming Facebook; 1) starting from creating an online Facebook group, 2) entering the design phase or design begins with entering or clicking on the facebook application, and then create a class facebook group, 3) write the name of the group of courses taught in class, 4) click type closed groups, 5) click to find the link, 6) click "Share" to see the class group link, 7) click copy to the clipboard. Student responses to learning are good, thus this learning design can be applied in the classroom. so the result of this design steps, They can practice learning English, especially speaking in live streaming video, which is a new activity for students on social media, namely Facebook.
\end{abstract}

Keywords: Design, English, live streaming in Era 4.0, Pandemic, Covid-19

\section{Abstrak}

Dalam article ini, live streaming menggunakan gadget sebagai sarana pembelajaran English speaking di era Pandemi Covid-19 dengan memanfaatkan salah satu platform media sosial yakni facebook. Penelitian ini merupakan penelitian kualitatif deskriptif, digunakan pada 40 siswa. Hasilnya mengidentifikasi tujuh langkah membuat grup Facebook dan perangkat pembelajaran untuk menghasilkan unit perkuliahan, lembar kegiatan mahasiswa, dan LKS. Hasil analisis dari penelitian ini membahas tujuh langkah desain pembelajaran bahasa Inggris perangkat pembelajaran bahasa Inggris berbasis live streaming Facebook; 1) dimulai dari membuat grup facebook online, 2) memasuki tahap desain atau desain dimulai dengan masuk atau mengklik aplikasi facebook, kemudian membuat grup facebook kelas, 3) menulis nama grup mata kuliah yang diajarkan di kelas, 4) klik ketik grup tertutup, 5) klik untuk menemukan tautan, 6) klik "Bagikan" untuk melihat tautan grup kelas, 7) klik salin ke clipboard. Respon siswa terhadap pembelajaran sudah baik, sehingga desain pembelajaran ini dapat diterapkan di dalam kelas. Pembelajaran bahasa Inggris khususnya Speaking dapat mereka praktikkan dalam live streaming video yang menjadi aktivitas baru bagi mahasiswa di social media yakni Facebook.

Kata kunci: Desain, Bahasa Inggris, Live streaming Era 4.0, Pandemi, Covid-19 


\section{INTRODUCTION}

Digital is an inseparable part of daily life. Digital is needed by humans today. Digital is also a basic need for activities both at home and at work. With the coming of the internet era that does not limit space and time, namely the expansion of internet connections to various regions, without the digital literacy capabilities of internet users will have difficulty utilizing the information they get and even shifted their focus to notifications that disrupt their productivity. Notifications from reminder applications, such as e-mail, or chat that continue to exist all the time, will transform how humans, individually or in groups, behave, work, and make decisions.

Digital literacy is literacy in using technology. According to (ELearning Department, 2015) that every educator must understand that digital literacy is very important if we want our students to use digital well. Internet connectivity and applications are presented very broadly, one of which is Facebook which has a live streaming feature that can be utilized in the world of education, so lecturers should show how to utilize digital internet in learning properly and appropriately. So in this study, the authors examined digital literacy in English learning based on live streaming of the 4.0 in pandemic covid-19 era.

Live streaming is an interactive live video that can monitor students during the learning process so that the benefits of learning can be achieved to the fullest. Live streaming as a research base in research that is also compatible with education 4.0. (Austerberry, 2004) states that "Streaming media is delivered directly from the source to the player in real-time. Streaming media presents professional communicators with a whole new way to deliver information, messages, and entertainment. "

According to (Changas, 2016) that "Facebook nowadays is the social network characterizing in a better way these networks are part of people daily, in special people that don't use only the Internet but have there its study object. (Facebook and Education). " Digital in the world of learning needs to be straightened out for students to use the digital they have for their learning purposes. English Learning Based on Live Streaming is learning-related problems in the current pandemic conditions.untuk of Digital Era 4.0 in Covid-19, implementing a quality learning process, so it is necessary for creativity to develop online-based learning, so Lecturers show the implementing by created learning designs using digital android mobile based on live streaming. Live streaming is also done on one of the social media namely Facebook.

\section{Study Activities}

(Piaget, 2002) explains that a student thinks as long as he does. Without deeds means that students do not think. Therefore, for students to think for themselves they must be allowed to act on their own.

(McKeachie, 1986) in measuring the level of student activity in learning there are seven dimensions as follows: Student participation in determining the objectives of teaching and learning activities, Emphasis on affective aspects in teaching. Student participation in carrying out teaching and learning activities, the main form of interaction between students, Acceptance of lecturers on student actions and contributions that are less relevant or wrong, Closeness of class relations as a group, Opportunities given to students to make important decisions in activities on campus.

\section{Learning model}


Through the learning model, lecturers can help students get information, ideas, skills, ways of thinking, and expressing ideas. The learning model also functions as a guide for learning designers and lecturers in planning teaching and learning activities.

Based on (Weil, 2003) states that the learning model is a plan that can be used to develop a learning plan, in the long run, design learning materials and conduct guidance in the learning process. Learning models can help students in exploring information, ideas, skills, and ways of thinking. Furthermore (Rusman, 2012) explained that now or in the future, the role of the teacher / lecturer is not only as a teacher (transmitter), but he must start to act as director of learning, namely as a manager of learning that facilitates student learning activities through the use of and optimization of various learning resources, it is not even impossible in the future the role of the media as the main source of information in learning activities (learning patterns in media), such as the application of computer-based learning (computer-based instruction), here the teacher's role is only as a learning facilitator only.

Learning models are usually arranged based on various principles or theories of knowledge. Experts arrange learning models based on educational principles, psychological, sociological, psychiatric, systems analysis, or other theories (Weil, 2003). Joyce \& Weil learn learning models based on learning theories which are grouped into four learning models. According to (Suprijono, 2009) the learning model refers to the approach to be used, including learning objectives, stages in learning activities, learning environment, and classroom management.

\section{Education 4.0}

Education 4.0 which has become more advanced can be regarded as the future of education and ready to change how the consumption of information changes drastically, education 4.0 can complement the digital phenomena in our daily lives, with the presence of education 4.0 in the era of the increasingly advanced industrial revolution, students will be prepared to face digital challenges directly. The point in this 4.0 era is creative skills which will certainly enable students to open or find a way out for them from the challenges of development they face.

(Changas, 2016) that there is education on Facebook. Facebook is currently a social network that is a part of people every day, people not only use the Internet by sharing statuses, photos or videos, but there are objects of study. Researchers are interested in seeing how a particular topic appears on Facebook and how to configure it as an object of study in a dialogue environment.

According to (Krahe, 2005) "Mapping learners' language and computing skills over time have been enlightening and have helped tailor introductions to the needs of individual groups. This means that "Mapping the language and computer / online abilities of trainees from time to time has been enlightening and has helped to adapt the introduction to the needs of each group. On Facebook it is also permissible to create a closed group that functions as a private virtual space, where anyone can interact via text, audio, video and / or picture messages. Thus, Facebook is used not only for personal status updates but also for academic use.

According to (Austerberry, 2004) that "live-streaming is often referred to as real-time; this is a somewhat vague term. It implies viewing an event as it happens. "This means that streaming is a real live broadcast in the place where the live broadcast is. This is a challenge for students in the 4.0 education era to enhance online and offline learning activities. Facebook live streaming can make students more creative in doing online learning.

(Scheibe, Fietkiewicz, \& Stock, 2016) in his article explained that when talking about live streaming it is a real program when someone wants to use live streaming then he will 
prepare himself, then prepare his tools, appearance and what he will say or check the sound. Furthermore (Bijnen, 2004) said that it is easy to access web-based video and audio media which should be common in online education and e-learning to improve visual literacy.

According to (Bersin, 2004) that everything has a natural rhythm. In the sense that offline learning has a rhythm marked by face-to-face meetings, learning in class, weekly practice in class, the independent practice also in the class, and mid-term and final assessment. The closeness of the session in place creates a rather tight and focused rhythm that requires all students to be in sync, and in online learning also requires students to be in sync.

Then in research from (Kitchenham, Tappenden., 2011) that lecturers facilitate student learning in an environment where each student is responsible for his learning, and there are also new challenges that must be faced. There is a need to understand new literacy, must be competent in how to disseminate and receive digital information.

\section{METHOD}

This research is used qualitative descriptive research. The research location is at the Faculty of Language and English Literature alauddin Makassar state Islamic university. The subject of the study was the 4rd-semester students participating in the Engliksh speaking course, involving 1 group of 2017 classmates as many as 40 people. The instrument used test of trial live streaming by using questionare. The result identified seven steps to create a Facebook group and learning tool to produce lecture units, student activity sheets, and student worksheets

Prcedure to get the data, directly giving test the students in the class and then ask them to follow the instruction of step in the learning design. There were 40 students given a trial to carry out the design of live streaming activities suit in pandemic covid-19 era, explanation in the following order: 1) starting from creating an online Facebook group, 2) entering the design phase or design starting with entering or clicking on the facebook application, and then creating a class facebook group , 3) write the name of the group of courses taught in class, 4) click type closed groups, 5) click to find the link, 6) click "Share" to see the class group link, 7) click copy to the clipboard. Student responses to learning are good, thus this learning design can be applied in the classroom.

\section{RESULT AND DISCUSSION}

The result of this reseach found online learning activity by using live streaming in Facebook group.The choice given is a live streaming design test of Easy and Difficulty level, which shows that with the Easy stage, students easily carry out the design stages and at the difficulty stage students find obstacles in this design trial. 


\section{FIGURE AND TABLE}

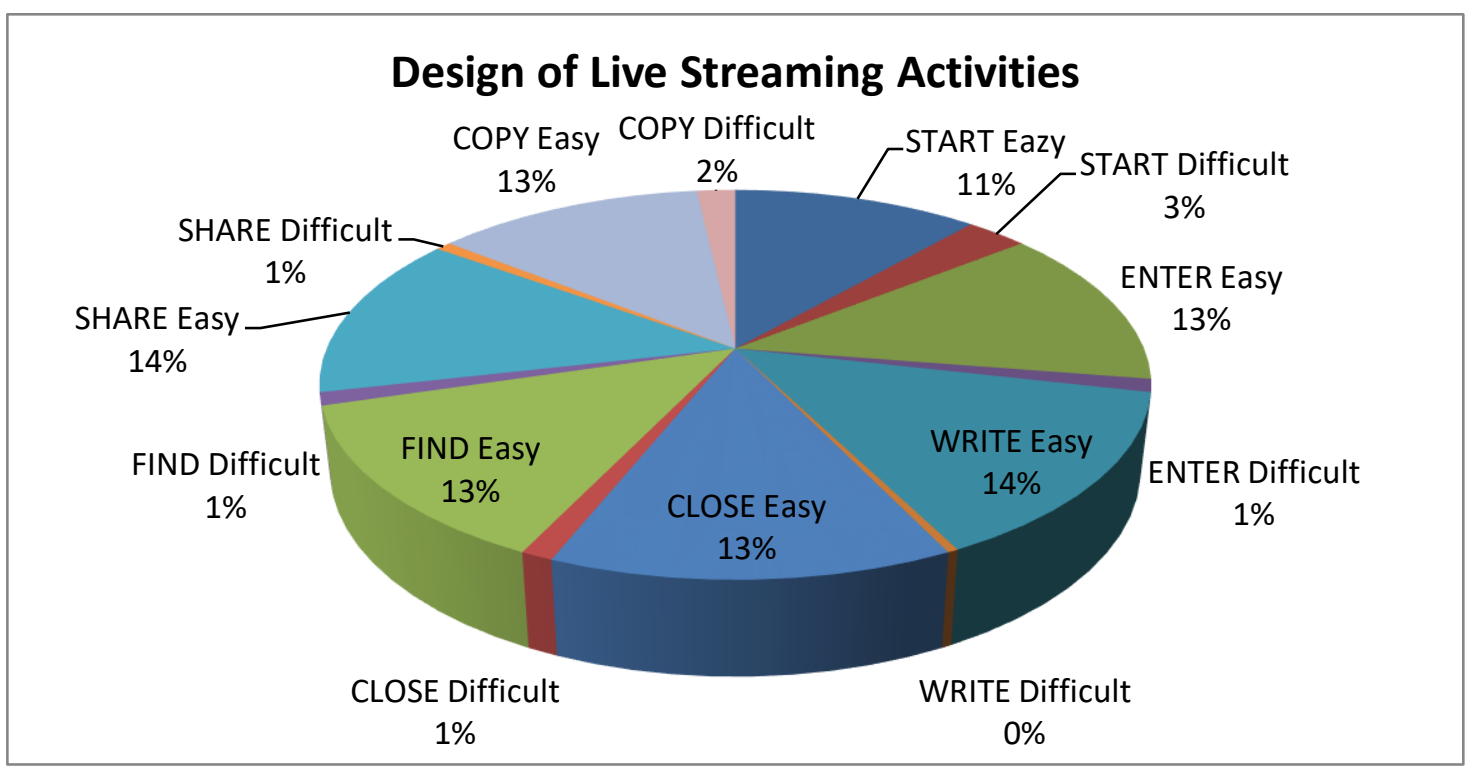

The graph above shows the percentage of student trials in the design of live streaming activities, overall at the easy level.

The chart above shows that: 1) Starting from creating an online Facebook group, there are 32 students at the easy level and 8 at the difficulty level, 2) Entering the design phase or design starting with entering or clicking on the facebook application, and then creating a class facebook group, there are 37 students at the easy level and 3 at the difficulty level, 3) Write the name of the group of courses taught in class, there are 39 students at the easy level and 1 at the difficulty level, 4) Click closed type groups, there are 37 students at the easy level and 3 at the difficulty level, 5) Click to find the link, there are 37 students at the easy level and 3 at the difficulty level, 6) Click "Share" to see the class group link, there are 38 students at the easy level and 2 at the difficulty level, 7) Click copy to the clipboard. Student responses to learning are good, thus this learning design can be applied in the classroom, and there are 35 students at the easy level and 5 at the difficulty level

There are seven steps in designing the LSF model. The first step: starting from creating an online Facebook group. In the picture below every Android cellphone, today is equipped with a Facebook application, which of course in logging into your personal Facebook must create an account, keep your user and password confidential. Facebook live streaming learning activities (LSF) can be free and free to use so that lecturers can direct students to participate in Facebook online groups. In designing or designing an LSF model, this is very effective because one of the social media applications "Facebook" is an application that is already common, and when buying an Android mobile phone is already installed on each android phone, and it's easy to download the application on the Playstore page. The facebook icon looks like this one with the sign (f) facebook with a white, blue background.

The second step: entering the design phase or design begins with entering or clicking on the facebook application, and then create a class facebook group. The design procedure for 
lecturers to create a Facebook group for this class needs to be known by every lecturer supporting a subject or student who wants to create a group, be it for personal interests or other interests.

Third step: next write the name of the group of courses taught in class. In the picture below, it was designed with a screenshot and then gives a cloudy round sign and gives the writing next to it "Write a Group Name".

Step four: click type Closed Groups, then Confidential. In the picture below you can see select privacy. There are public choices; anyone can find groups, see who their members are and their posts. This category is a general category, anyone who sees our Facebook homepage will be seen by everyone in this world for those who use Facebook social media. There are closed options, anyone can find a group and see who runs it. Only members can find who is in it and what they post. This category is a privacy category that might still exist that can join a Facebook group outside the class that is being taught. However, it is possible to set up or arrange if anyone wants to join our class group, then there will be an incoming notification to request approval (approval) so the lecturer can filter or filter out students who will join the Facebook class group. There is a secret choice, only members can find the group, see who its members are, and what is posted. This category is a choice of confidential privacy, which is why, if the lecturer has agreed to everything and is sure that the student is already a member of the class Facebook group that has been created, the lecturer may set up or arrange a closed group to a secret group, so that, no other account is created. can enter the group. Except for students who have been approved or approved. In this picture, it is designed by giving the text "Select Closed".

Step five: click to find the link. The use of the arrow symbol is a short way to find the Facebook group class link that has been created by the lecturer. In the picture below it is designed by giving the words "click here"

Step six: click "Share" to see the Class group link. In this section, please "click here" then several items will automatically appear, such as the seventh capture image.

Step seven: Click Copy to the clipboard, then it will automatically copy the Link Group class. It can be sent directly to the chairman of the level or share the link in google classroom. When students click on the link they will enter the group through group admin approval.

Then in the design phase or this design, making a live stream. There are two ways to stream live, if the lecturer wants a video that does not need to be edited, it is real life, then enter the live streaming menu which is automatically available in the Facebook feature, and if you want the video to be edited or a network outage occurs, you can make a live stream video recording and then send it immediately after recording the video to the class facebook group.

Learners and lectures could practice this design that suit in pandemic covid-19, most of the students and the lectures study and work from home.

\section{CONCLUSION}

The design of the learning model by creating a Facebook group then designing the learning device and the seven stages of design to carry out live streaming facebook according to the learning device suit during pandemic covid-19 era, the results of which look very good. This online learning by applying live streaming on the Facebook group can be an alternative for 
online learning. But through this research, researcher also get a problem, namely a weak signal so that students may not be able to do live streaming, but the solution is to record their own videos and then send them to a Facebook group. The resulting design is that the LSF model needs a support system, namely, delivering and orienting students about live Facebook streaming, organizing students in learning, creating a Facebook group class link and sharing the Facebook group link to the classroom or to the level leader, providing direction or rules about live streaming on Facebook, delivering the assignment rules, presenting and presenting material, giving awards and assessments.

\section{REFERENCES}

Austerberry, D. (2004). The Technology of Video \& Audio Streaming (Second Edi). Focal Press is an Imprint of Elsevier.

Bersin, J. (2004). The Blended Learning Book.

Bijnen, M. (2004). Handbook on Digital Video and Audio in Education e Video Aktiv Project (Creating and Using audio and Video Material for Educational Purposes). VideoAktiv Project. Retrieved from www.videoaktiv.org

Changas, A. (2016). Facebook and education. Post, like \& share. Campina Grande $\mathrm{PB}$.

ELearning, D. of. (2015). Digital Literacy: 21st Century Competencies for Our Age The Building Blocks of Digital Literacy From Enhancement to Transformation. (21st Centu).

Faasen, M. (2016). A Learning Design Framework for Active Learning using Audience Response Systems, (March).

ussin, A. A. (2018). Education 4 . 0 Made Simple: Ideas For Teaching. International Journal of Eduction \&Literacy Studies, 6(3), 92-98.

Kitchenham, Tappenden., A. (2011). Blended Learning across Disciplines: Models for Implementation. Experiences from a New Zealand Faculty of Law. University of Waikato, New Zealand.

Krahe, B. (2005). Perilaku Agresif. Yogyakarta: Pustaka Pelajar.

McKeachie, W. (1986). Teaching Tips: A Guidebook for Beginning College Teacher. Boston, D.C. Health. Boston: D.C. Health.

R.D.Harahap,"Analysis of Teaching Teachers of High School Private Vocational School, Districtpanai Hulu District, Labuhanbatu. International Journal of Innovative Science and Research Technology. Volume 5, Issue 3, March - 2020

Scheibe, K., Fietkiewicz, K. J., \& Stock, W. G. (2016). Information Behavior on Social Live Streaming Services. Journal of Information Science Theory and Practice, $4(2), 6-20$.

Weil, B. J. M. (2003). Model of Teaching. Fifth Edition. New Delhi: Prentice Hall. 